\title{
Nationale constitutie versus internationale jurisdictie?
}

\section{De rol van de rechter vanuit internationaalrechtelijk perspectief}

\author{
Anneloes Kuiper-Slendebroek
}

Voor nationale rechters vormt de ontwikkeling van het internationale recht en hun rol hierin een uitdaging. Het vermogen van de rechter om internationaal recht ${ }^{1}$ te interpreteren en toe te passen, is onderworpen aan constitutionele regels. Tegelijkertijd is toetsing van nationale wetgeving door de rechter van belang voor het behartigen van belangen van burgers en een tegenwicht voor politieke voorkeuren in het beschermen van bepaalde nationale belangen:

'[N]ational courts have come to realize that, under conditions of increased external pressure, allowing the government carte blanche to act freely in world politics actually impoverishes the domestic democratic and judicial processes and reduces the opportunity of most citizens to use these processes to shape outcomes. ${ }^{2}$

Deze rol van de Nederlandse rechter en diens verhouding tot de andere staatsmachten - met name de verhouding tussen de wetgevende en de rechterlijke macht - wordt veelal bezien vanuit het staatsrecht. Bij het rechtstreeks toepassen van internationale verdragsbepalingen door de Nederlandse rechter spelen diens staatsrechtelijke positie en de artikelen 93 en 94 Grondwet immers een grote rol. Maar de rechter heeft ook te maken met de interpretatieregels uit het internationale recht en de wisselwerking die bestaat tussen internationaal en nationaal recht. Deze invalshoek blijft vaak onderbelicht, terwijl de invloed van het internationale recht op de nationale rechtsorde steeds groter wordt. Het aloude beginsel van de scheiding der machten is hierbij nog steeds actueel, maar deze moet worden bezien vanuit een hedendaagse, grensoverschrijdende context. Dit artikel beziet daarom de rol van nationale rechtspraak en de Nederlandse rechter vanuit het internationaal publiekrecht.

Voor een goed begrip van het onderwerp wordt in paragraaf 1.1 het kader geschetst van het ontstaan van internationaal recht: wat zijn de belangrijkste

1 Het betreft hier het internationaal publiekrecht, ook wel 'volkenrecht' genoemd. De beschrijvingen in dit artikel betreffen niet het recht van de Europese Unie (hierna: EU), onder meer vanwege de bijzondere positie van het Europese Hof van Justitie als hoogste rechter voor de EU-lidstaten en de wijze van doorwerking van EU-recht in de Nederlandse rechtsorde die verschilt van de doorwerking van het overige internationale recht.

2 E. Benvenisti, 'Reclaiming democracy: the strategic uses of foreign and international law by national courts', The American Journal of International Law, 102 (2008), 248. 
rechtsbronnen, hoe verbindt de staat zich aan internationaal recht en welke verplichtingen vloeien hieruit voort? In paragraaf 2 worden de verschillende rollen van rechtspraak en rechter uiteengezet: paragraaf 2.1 bespreekt de legitimerende rol van de rechtspraak met betrekking tot het identificeren en interpreteren van internationaal recht en in paragraaf 2.2 worden de verschillende rollen van de nationale rechter toegelicht. In paragraaf 3 wordt het nationaalrechtelijk kader uiteengezet: in paragraaf 3.1 komt kort de Nederlandse constitutionele inrichting aan bod waarna in paragraaf 3.2 de handhavende rol van de Nederlandse rechter via de rechtstreekse werking van internationaal recht in de praktijk aan de orde komt. Deze praktijk bestaat met name uit twee kenmerkende arresten uit de Nederlandse rechtspraak: het Spoorwegstakingsarrest uit 1986 en het Rookverbodarrest uit 2014. In paragraaf 4 volgt een korte conclusie.

\section{Ter inleiding: het ontstaan van internationaal recht}

Internationaal recht wordt gevormd door verschillende bronnen, zoals verdragen en gewoonterecht. Bij het ontstaan van deze bronnen zijn met name staten betrokken. Naast staten en internationale organisaties wordt ook aan natuurlijke personen een zekere plaats in het internationale recht toegekend en zijn er in het internationale recht bepaalde rechten en plichten voor individuen gecreëerd. ${ }^{3}$ In deze paragraaf wordt eerst een overzicht gegeven van de verschillende bronnen en de werking van internationaal recht.

Omwille van het horizontale karakter kent het internationale recht geen normenhiërarchie, behalve voor dwingendrechtelijke ius cogens-normen. ${ }^{4}$ Het internationale recht kan aan verschillende bronnen worden ontleend. De belangrijkste bronnen worden in deze paragraaf besproken aan de hand van de bekende - maar niet uitputtende - opsomming van bronnen van internationaal recht uit artikel 38 Statuut van het Internationaal Gerechtshof (hierna: IGHstatuut):

'a internationale verdragen, zowel van algemene als van bijzondere aard, waarin regels worden vastgelegd die uitdrukkelijk door de bij het geschil betrokken staten worden erkend;

b internationale gewoonte, als blijk van een als recht aanvaarde algemene praktijk;

c de door beschaafde naties erkende algemene rechtsbeginselen;

d [...] rechterlijke beslissingen, alsmede de opvattingen van de meest bevoegde schrijvers der verschillende naties, als hulpmiddelen voor het bepalen van rechtsregels.'

3 R. McCorquodale, 'The Individual and the international legal system, in International Law, red. M.D. Evans (2014), 280-282.

4 M. Bossuyt \& J. Wouters, Grondlijnen van internationaal recht, (Antwerpen-Oxford: Intersentia 2005), 140. 
Verdragen en gewoonterecht zijn primaire rechtsbronnen, algemene rechtsbeginselen zijn een subsidiaire rechtsbron. ${ }^{5}$ Voor het ontstaan van gewoonterecht zijn twee componenten nodig: de statenpraktijk en de opinio juris, de overtuiging dat de regel als recht dient te gelden. Als hulpmiddelen voor het vaststellen van de primaire rechtsbronnen worden de (inter)nationale rechtspraak en literatuur genoemd. Dit zijn hulpbronnen die helpen bij het vaststellen, becommentariëren, uitleggen en eventueel bekritiseren van het bestaande recht. ${ }^{6}$

Verdragen vormen in de praktijk de belangrijkste rechtsbron. ${ }^{7}$ Het voordeel van een verdrag boven gewoonterecht ligt in de wijze van totstandkoming, de rechtszekerheid, de gebondenheid van partijen tot het te goeder trouw uitvoeren van het verdrag en de invloed die door partijen kan worden uitgeoefend op de inhoud. Op verdragen tussen staten is het Weens Verdragenverdrag ${ }^{8}$ (hierna: WVV) (lex generalis) van toepassing voor zover in de desbetreffende overeenkomst niet anders is bepaald (lex specialis). Uit het WVV blijkt een voorrang van internationaal recht op nationaal recht. Het bevat onder meer de bepaling dat een staat in de geest moet handelen van een verdrag dat hij heeft ondertekend, ook wanneer het verdrag nog niet in werking is getreden. ${ }^{9}$ Een verdrag heeft effect in het nationale recht overeenkomstig nationale regels, maar het nationale recht mag de werking van een verdrag niet belemmeren. ${ }^{10}$ Ook moet bij interpretatie van verdragen rekening worden gehouden met ontwikkelingen ná sluiting van het verdrag, zoals

'ieder later gebruik in de toepassing van het verdrag waardoor overeenstemming van de partijen inzake de uitlegging van het verdrag is ontstaan'.11

Dit 'later gebruik' - de subsequent practice - is een belangrijk element bij het bepalen van de betekenis van een verdrag. Het bestaat uit de (consistente) praktijk van staten met als intentie het verdrag te goeder trouw te interpreteren. Hieruit kan een gemeenschappelijk inzicht van partijen over het verdrag worden afgeleid. Voor de kwalificatie van dit 'later gebruik' is in de literatuur een aantal voorwaarden gesteld, waarbij een grote rol is weggelegd voor de praktijk van staten als verdragspartijen:

5 N. Schrijver, 'De kraamkamers van het internationale recht', in Recht in geding II, red. M. Groenhuijsen, E. Hondius \& A. Soeteman (Den Haag: Boom juridisch 2016), 114.

6 Art. 38(1)(d) IGH-statuut.

7 Bossuyt \& Wouters, Grondlijnen van international recht (Antwerpen-Oxford: Intersentia 2005), 38; H.W.A. Thirlway, 'The Sources of International Law', in International Law, red. M.D. Evans (Oxford: Oxford University Press 2014), 95.

8 Verdrag van Wenen inzake het verdragenrecht.

9 Art. $18 \mathrm{WVV}$.

10 Art. 27 WVV.

11 Art. 31(3)(a, b) WVV. 
'Above all intentionality is required (...): to qualify as practice a conduct must be linked to the acting party's belief that its conduct reflected a position taken on the interpretation of the treaty. Furthermore, commentators agree that in addition to intentionality some degree of consistency is required. (...) Finally practice must be conduct in the application of the treaty. (...) The commentaries to the [Draft Articles on the Law of Treaties] state that all the parties to a treaty, not just some of them, must act in such a way as to evidence their agreement on the interpretation. However, the commentaries stress that this does not mean that all of the parties must actually engage in the practice - simply that any non-engaging party must acquiesce in the practice. $^{\text {'12 }}$

Als hulpmiddel voor bijvoorbeeld het vaststellen van deze zich verder ontwikkelende regels van internationaal recht en voor de interpretatie van internationale rechtsbronnen in het algemeen vermeldt het IGH-Statuut onder andere de nationale rechtspraak. Maar niet alleen als hulpmiddel draagt nationale rechtspraak bij aan de ontwikkeling van het internationale recht. Nationale rechtspraak is ook op zichzelf een bewijs van statenpraktijk, ${ }^{13}$ welke van belang is voor de interpretatie van verdragen en de vorming van gewoonterecht, een primaire rechtsbron:

'National courts are directly and indirectly engaged in the evolution of customary international law: their decisions that are based on international law are viewed as reflecting customary law. ${ }^{\text {'14 }}$

Deze beide zijden van nationale rechtspraak - hulpmiddel voor het vaststellen van internationaal recht en bewijs van statenpraktijk - wordt ook wel de 'dualiteit van nationale rechtspraak' genoemd. ${ }^{15}$ De nationale rechtspraak is daarmee van groot belang voor de ontwikkeling, uitleg en toepassing van internationaal recht. Daarnaast zijn ook de uitwisseling tussen nationale en internationale rechtspraak en de rol die de rechter in deze praktijk inneemt van belang. Deze onderwerpen worden uiteengezet in paragraaf 2 .

12 J. Arato, 'Subsequent Practice and Evolutive Interpretation. Techniques of Treaty Interpretation over Time and Their Diverse Consequences', Law and Practice of International Courts and Tribunals, 3 (2010), 459-460.

13 Art. 38(1)(d) IGH-Statuut. Zie ook A. Roberts, 'Comparative International Law? The role of national courts in creating and enforcing international law', International Comparative Law Quarterly, 60 (2011), 62.

14 Benvenisti, 'Reclaiming democracy: the strategic uses of foreign and international law by national courts' (2008), 248.

15 Roberts, 'Comparative International Law? The role of national courts in creating and enforcing international law’ (2011), 64. 


\section{Legitimatie door de rechtspraak en de rol van de nationale rechter}

Het internationale recht is niet statisch, maar dynamisch: internationaal recht wordt mede gevormd door de interactie met nationaal recht. In paragraaf 2.1 wordt de plaats van de rechtspraak in dit proces uiteengezet. Daarnaast is voor de ontwikkeling van internationaal recht de interpretatie en toepassing van dit recht door de nationale rechter van belang. Hierbij kan de rechter een rechtsvormende of handhavende rol aannemen, hetgeen in paragraaf 2.2 wordt uiteengezet.

\subsection{Internationale en nationale rechtspraak: identificatie en interpretatie}

Ten aanzien van de verplichtingen waaraan de staat internationaalrechtelijk is gebonden, vervult de nationale rechter een legitimerende rol. Dit komt duidelijk naar voren bij zowel de identificatie als de interpretatie van het internationale recht.

Om het internationale recht waaraan de Staat is gebonden te kunnen toepassen, moet de nationale rechter dit recht eerst identificeren en interpreteren. Hiervoor maakt de rechter idealiter gebruik van het WVV en de verschillende hulpmiddelen, met name de interpretatieregels in de artikelen 31-33 WVV. Daarna wordt het internationale recht - op een wijze die het nationale recht daarvoor aanwijst - in de concrete situatie toegepast. De uitspraak van de nationale rechter na het nemen van deze stappen, vormt vervolgens een hulpmiddel voor ándere nationale en internationale rechters bij het interpreteren en toepassen van internationaal recht.

Een voorbeeld van deze wisselwerking tussen internationale en nationale rechtspraak is te vinden in het Srebrenica-arrest van de Nederlandse Hoge Raad over de immuniteit van de Verenigde Naties (hierna: VN). In deze uitspraak identificeert de Hoge Raad het geldende internationaal gewoonterecht aan de hand van rechtspraak van het Europese Hof voor de Rechten van de Mens (hierna: EHRM) en de rechtspraak van het Internationaal Gerechtshof (hierna: IGH). Aan de interpretatie van deze twee internationale hoven voegt de Hoge Raad een eigen element toe, namelijk dat er wel verschillen bestaan tussen immuniteit voor internationale organisaties en staatsimmuniteit, maar dat dit volgens hem geen betrekking heeft op het recht op toegang tot de rechter. Hij gebruikt deze uitspraken als uitgangspunt en voegt een nieuwe interpretatie toe aan het recht betreffende de immuniteit van internationale organisaties:

'De tussenconclusie moet zijn dat het hof ten onrechte (...) heeft onderzocht of het ten behoeve van de VN gedane beroep op immuniteit moet wijken voor het recht op toegang tot de rechter als bedoeld in art. 6 EVRM. Die immuniteit is absoluut. Het handhaven daarvan behoort bovendien tot de verplichtingen van de leden van de VN die, zoals ook het EHRM in Behrami, Behrami en Saramanti in aanmerking heeft genomen, ingevolge art. 103 Handvest VN in geval van strijdigheid voorrang hebben boven verplichtingen krachtens andere internationale overeenkomsten. (...) En tenslotte oordeelde 
het IGH dat in de statenpraktijk waaruit het internationaal gewoonterecht wordt afgeleid, geen grond te vinden is voor het oordeel dat naar internationaal recht aan een staat slechts immuniteit toekomt ingeval is voorzien in een effectieve alternatieve wijze van geschilbeslechting. Hoewel de VN-immuniteit te onderscheiden valt van staatsimmuniteit, is niet sprake van een verschil dat rechtvaardigt met betrekking tot de verhouding tussen eerstgenoemde immuniteit en het recht op toegang tot de rechter anders te oordelen dan het IGH heeft beslist ten aanzien van de verhouding tussen staatsimmuniteit en het recht op toegang tot de rechter.' ${ }^{\text {16 }}$

Niet alleen vanuit de nationale recht wordt het internationale recht geïnterpreteerd en toegepast, ook in de internationale rechtspraak wordt rekening gehouden met ontwikkelingen in het nationale recht en de nationale rechtspraak. Zo zoekt het EHRM voor de interpretatie van het EVRM aansluiting bij breed gedeelde opvattingen in de verschillende verdragsstaten en in internationaal verband. ${ }^{17}$ In dat kader kan het EHRM naast de nationale rechtspraak in lidstaten bijvoorbeeld ook niet-geratificeerde verdragen en 'soft law' in zijn beoordeling betrekken. Aan deze 'common ground-methode' wordt ook door de Nederlandse Hoge Raad gerefereerd bij de interpretatie van de artikelen 2 en 8 EVRM:

'Bij de uitleg van het EVRM dient volgens de rechtspraak van het EHRM voorts rekening te worden gehouden met relevante regels van internationaal recht als bedoeld in art. 31 lid 3, onder c, van het [WVV]. (...) Voorts dient, overeenkomstig art. 31 lid 3, aanhef en onder b, van het [WVV], bij de uitleg van verdragsbepalingen rekening te worden gehouden met de toepassingspraktijk in de lidstaten. (...) Blijkens de rechtspraak van het EHRM dient bij de uitleg en toepassing van het EVRM voorts rekening te worden gehouden met wetenschappelijke inzichten en algemeen aanvaarde standaarden. ${ }^{18}$

Het internationale recht wordt ontwikkeld en versterkt door de interpretatie en toepassing ervan door de nationale rechter. Vervolgens wordt met deze nationale interpretatie rekening gehouden door internationale gerechtshoven, zoals het EHRM. En niet alleen voor de interpretatie, maar ook voor diens legitimatie is het internationale recht afhankelijk van de nationale rechtspraak:

' $[F]$ rom the perspective of the complex interplay between international and national courts, the international tribunals are dependent to a certain extent on national courts, because they need the latter's cooperation to implement

17 Zie bijvoorbeeld EHRM 12 september 2012, nr. 10593/08 (Nada/Zwitserland); EHRM 12 november 2008, nr. 34503/97 (Demir en Baykara/Turkije); EHRM 27 januari 2009, nr. 67021/01 (Tãtar/Roemenië).

18 HR 20 december 2019, ECLI:NL:HR:2019:2006, r.o. 5.4.2-5.4.3 (Urgenda). 
their decisions. A national court that seriously applies international law sends a strong signal to international courts that the national court regards itself as an equal participant in the transnational lawmaking process and will not accept just any decision rendered by an international tribunal. ${ }^{19}$

De interactie tussen internationale en nationale rechtspraak is voor beide rechtsordes een gangbare praktijk en leidt tot een verdere ontwikkeling en legitimatie van het internationale recht. Voor het interpreteren en toepassen van het internationale recht in de nationale rechtsorde is een grote rol weggelegd voor de nationale rechter. Deze wijzen waarop deze rol kan worden ingevuld wordt in de volgende paragraaf uiteengezet.

\subsection{De rol van de nationale rechter: mantel of schild}

De interactie tussen nationaal en internationaal recht bestaat niet uit een automatisch proces waarbij internationaal recht wordt omgezet in nationaal recht, maar is een 'process of translation from international to national'. ${ }^{20} \mathrm{Er}$ bestaan net zoveel verschillen in interpretatie van het internationale recht als er nationale rechters zijn die dit recht interpreteren. Dit staat haaks op de overtuiging dat het internationale recht een overkoepelend systeem is waar een consensus ten opzichte van juridische normen te vinden is:

'The determination of international custom or general principles of law abstracts from the laws and practices of different cultures in order to formulate an international legal norm that expresses what is common and therefore acultural. (...) Since this disembeddedness lends the resulting norm an air of neutrality and thus legitimacy, its domestic application is assumed to be straightforward. While an international legal norm may leave room for culture (...) this does not affect the interpretation of the obligation as far as it goes. $^{21}$

De aanname dat betekenis van een norm te vinden is in de tekst en daarom niet per staat kan verschillen blijkt niet uit de dagelijkse praktijk. ${ }^{22}$ Elke Staat interpreteert het internationale recht vanuit een eigen cultuur, taal en rechtssysteem. Dit leidt tot een nationalisatie van internationaal recht waarbij

19 Benvenisti, 'Reclaiming democracy: the strategic uses of foreign and international law by national courts' (2008), 248-249.

20 K. Knop, 'Here and there: International Law in Domestic Courts', International Law and Politics, 32 (2000), 506.

21 Knop, 'Here and there: International Law in Domestic Courts' (2000), 527.

22 Voor een internationale casus waarin deze verschillende interpretaties per staat naar voren komen: zie IGH 3 februari 2012, Jurisdictional Immunities of the State (Germany v. Italy : Greece intervening), Judgment, I.C.J. Reports, 99. Zelfs voor nationale rechterlijke instanties blijkt het niet altijd mogelijk op een lijn te zitten: zie de uiteenlopende interpretaties van het internationale verdragsrecht door rechtbank en hof Den Haag in de Yukoszaak, Rb. Den Haag 20 april 2016, ECLI:NL:RBDHA:2016:4230 en Gerechtshof Den Haag 18 februari 2020, ECLI:NL:GHDHA: 2020:234. 
het gebruik van nationale juridische terminologie niet te vermijden is. ${ }^{23}$ Het internationale recht kan daarom aan betekenis verliezen in de vertaling naar nationaal recht. Dit kan leiden tot de overtuiging dat verschillende interpretaties niet allemaal de juiste kunnen zijn $^{24}$ of tot het uitgangspunt dat verschillende interpretaties leiden tot een positieve ontwikkeling van het internationale recht. De verschillen in interpretatie betekenen immers niet per se dat staten het oneens zijn over de waarheid, maar dat ze komen tot een internationale samenleving waarin deze verschillen, hetzij reden voor discussie en aanscherping, hetzij verrijkende invalshoeken blijken te zijn. ${ }^{25}$ Deze wisselwerking tussen nationaal en internationaal recht kan beide rechtstelsels versterken, dankzij de rol van de nationale rechter hierin:

'If we accept that national courts act as both norm internalizers and norm creators, then international law may be somewhat lost in translation from the international to the domestic, but international law is also found in translation as domestic courts help to constitute international law. ${ }^{26}$

Hoewel de nationale rechter zich ten behoeve van de ontwikkeling van het internationale recht zou moeten gedragen als norm creator of rechtsvormer, gedraagt hij zich vaker als een onafhankelijke rechtshandhaver. Roberts geeft twee verklaringen voor dit gedrag. ${ }^{27}$ De eerste verklaring is dat de rechter de rol van rechtshandhaver aanneemt, maar enkel om deze te gebruiken als dekmantel voor een progressieve ontwikkeling van het internationale recht. Onder de mantel houdt de rechter zich dus eigenlijk actief bezig met rechtsvorming. De tweede verklaring is dat de rechter de rol als rechtshandhaver gebruikt als een schild om passiviteit te rechtvaardigen en kritiek af te weren vanwege het niet verder ontwikkelen van internationaal recht.

Mantel en schild zijn beide te relateren aan de constitutionele structuur van de staat. Wanneer de rechter enkel bevoegd wordt geacht om bestaand recht toe te passen, maar wel een rol als internationale rechtsvormer op zich wil nemen, kan dit alleen door internationaal recht te ontwikkelen onder de mantel van rechtshandhaving. En wanneer de nationale wetgever een hiërarchisch hogere positie heeft en daarmee een exclusieve rol als ontwikkelaar van het internationale recht inneemt, wordt de nationale rechter beperkt tot het handhaven van de door de wetgever in nationale wetgeving opgenomen internationaalrechtelijke normen.

23 Roberts, 'Comparative International Law? The role of national courts in creating and enforcing international law' (2011), 74.

24 R. Bahdi, 'Trut hand Method in the Domestic Application of International Law', Canadian Journal of Law and Jurisprudence, 15, no. 2 (2002), 262.

25 Zie ook H.G. Gadamer, Waarheid en methode. Hoofdlijnen van een filosofische hermeneutiek (Nijmegen: Uitgeverij Vantilt, 2014).

26 Roberts, 'Comparative International Law? The role of national courts in creating and enforcing international law’ (2011), 80-81.

27 Roberts, 'Comparative International Law? The role of national courts in creating and enforcing international law' (2011), 70-71. 
Het gevolg van een statische toepassing van de door de wetgever bepaalde internationaalrechtelijke normen is dat de ontwikkeling van het internationale recht komt stil te staan. Deze normen kunnen zich dan alleen ontwikkelen door afspraken tussen staten die worden neergelegd in verdragen, besluiten en het nationale recht. Omdat bepaalde normen of het internationaal gewoonterecht - onderwerpen als jurisdictie en (staats)immuniteit - zich per definitie ontwikkelen via de rechterlijke toepassing kan dit problematisch worden.

Het uitgangspunt van het internationale recht is dat de afspraken waaraan de staat zich heeft verbonden daadwerkelijk door hem in acht worden genomen, ook in de nationale rechtsorde. ${ }^{28}$ Het hoort bij de rechterlijke taak om de betrokkenen aan het geldende recht te houden en dit toe te passen zodat het beoogde effect wordt bereikt. Hiervoor biedt het internationale recht aan nationale rechters belangrijke handvatten:

'They tap into the rich jurisprudence developed by international tribunals concerning "effective", "evolutive", or "systemic" interpretation of treaties, or rely on the tribunals' unsystematic ways of identifying customary norms. Moreover, they base their interpretation of domestic legislation on the premise that the legislature does not intend to contravene international obligations. Finally, even domestically unincorporated treaties and custom are often treated as a relevant consideration for the executive when exercising its discretion under domestic authorizing statutes. ${ }^{29}$

De legitimerende rol van de rechtspraak sluit op deze wijze aan bij de rechtsvormende rol van de rechter. Het nationale recht is niet langer een op zichzelf staande eenheid, maar wordt gevormd en versterkt door een interactie met buitenlands en internationaal recht.

Elke staat heeft de verplichting om ook binnen de nationale rechtsorde de internationaal gemaakte afspraken na te komen. Daarnaast bevatten deze afspraken dikwijls ook rechten voor particulieren. Om als particulier een beroep te kunnen doen op hun rechten en de plichten van de staat, moeten de internationale regels en rechtsbronnen waaraan de Nederlandse staat is gebonden van toepassing zijn in de Nederlandse rechtsorde. De betreffende constitutionele bepalingen en ontwikkelingen in de Nederlandse jurisprudentie worden in de volgende paragraaf uiteengezet en afgezet tegen de rol van de rechter volgens het nationale én het internationale recht.

29 Benvenisti, 'Reclaiming democracy: the strategic uses of foreign and international law by national courts' (2008), 252. 


\section{De werking van internationaal recht via de Nederlandse rechter}

Voor de doorwerking van het internationale recht staan bepalingen opgenomen in de Nederlandse Grondwet sinds de jaren vijftig van de vorige eeuw, welke in 1983 voor het laatst werden aangescherpt. Maar ook daarna heeft het internationale recht zich verder ontwikkeld en zijn er verschillende nieuwe vormen van internationale organisaties en rechtsbronnen ontstaan. ${ }^{30}$ De Nederlandse staat verbindt zich aan internationale verplichtingen en de Nederlandse rechter wordt geacht zich uit te spreken over de juiste interpretatie of toepassing van deze (normen van) internationale rechtsregels bij het uitleggen van het Nederlandse recht. Voor de nationale rechter vormen deze ontwikkelingen en zijn rol hierin een uitdaging:

'de moderne rechter [zoekt] oplossingen voor complexe grensoverschrijdende problemen waar hij tegen aanloopt in een open en meerlagige rechtsorde als de onze. ${ }^{31}$

In paragraaf 3.1 volgt een korte toelichting op het Nederlandse constitutionele stelsel, waarna in paragraaf 3.2 de ontwikkelingen in de Nederlandse rechtspraak worden uiteengezet en de rol van de rechter als handhaver van het internationale recht wordt toegelicht.

\subsection{De nationale trechter van het internationale recht}

Het Nederlandse rechtsstelsel kent met betrekking tot de doorwerking van internationaal recht een gematigd monistisch systeem. ${ }^{32}$ Monistisch, omdat internationaal recht in beginsel rechtstreeks van toepassing is in de nationale rechtsorde, dus zonder omzetting in nationale wetgeving. Dit heeft tot gevolg dat niet alleen het verdragsrecht, maar ál het internationale recht dat de Nederlandse staat bindt, behoort tot het objectieve recht. ${ }^{33}$ De rechtskracht van bijvoorbeeld internationaal gewoonterecht en verdragen is automatisch en geldt indien en zodra deze internationaalrechtelijk gezien bindend zijn voor Nederland. ${ }^{34}$ Uit de presumptie dat een staat wordt vermoed zijn volkenrechtelijke verplichtingen te willen nakomen, volgt het beginsel dat een norm van nationaal recht nooit zó mag worden uitgelegd dat deze een volkenrechtelijke verplichting voor de staat

30 Zie ook: Rapport Staatscommissie Grondwet 2010, 99.

31 R. van Gestel \& M. Loth, 'Urgenda: roekeloze rechtspraak of rechtsvinding 3.0?', NJ 2015/17.

32 HR 3 maart 1979, NJ 1919, 371 (Grenstractaat Aken).

33 J.B. Mus, Verdragsconflicten voor de Nederlandse rechter (diss. Utrecht, 1996), 17; L.F.M. Besselink, 'Internationaal recht en nationaal recht', in Handboek Internationaal Recht, red. N. Horbach, R. Lefeber \& O. Ribbelink (Dan Haag: T.M.C. ASSER PRESS 2007), 63; B.A. KuiperSlendebroek, Rechter over Grenzen (diss. Leiden, 2017), 40.

34 J.W.A. Fleuren, Een ieder verbindende bepalingen van verdragen (diss. Nijmegen, 2004), 19; L.F.M. Besselink \& R.A. Wessel, De invloed van ontwikkelingen in de internationale rechtsorde op de doorwerking naar Nederlands constitutioneel recht. Een 'neo-monistische' benadering (2009), 42. 
schendt. ${ }^{35}$ Voor de rechter blijkt deze verplichting met name uit artikel 13a Wet Algemene Bepalingen:

'De regtsmagt van den regter en de uitvoerbaarheid van regterlijke vonnissen en van authentieke akten worden beperkt door de uitzonderingen in het volkenregt erkend.'

De invoering van dit artikel was het gevolg van een rechtbankvonnis ${ }^{36}$ aangaande staatsimmuniteit, waarin het Duitse Rijk bij verstek werd veroordeeld om aan de Nederlander De Booy een schadevergoeding te betalen omdat het Duitse Rijk 'door haar troepen opzettelijk en wederrechtelijk zijn met steenkolen beladen lichterschip De Booy II, heeft in den grond doen schieten, waardoor hij groote schade leed en nog lijdt'. ${ }^{37}$ In de bespreking bij opname van dit artikel in de Wet Algemene Bepalingen, wordt overwogen:

'Ten slotte werd tegen de voorgestelde bepaling, in haar beide onderdeelen, nog de bedenking aangevoerd, dat zij, de kracht van het volkenrecht voor ons nationaal recht ten aanzien van een enkel punt (de rechtsmacht van den rechter en de uitvoerbaarheid van vonnissen) vaststellende, aanleiding zou kunnen geven tot de opvatting dat voor andere onderwerpen het volkenrecht te onzent geen rechtskracht heeft en de rechter dus daarmede geen rekening heeft te houden. Dit ware echter in strijd met het standpunt, waarop ook de meerderheid der Staatscommissie zich heeft gesteld, "dat de beginselen van het volkenrecht, ook zonder dat daarmede in de nationale wet uitdrukkelijk is rekening gehouden, invloed uitoefenen op het burgerlijk recht", een standpunt, dat aan de hier aan het woord zijnde leden alleszins juist voorkwam. 38

Niet enkel ten aanzien van internationaalrechtelijke vraagstukken, zoals omtrent staatsimmuniteit, dient de rechter het internationale recht te betrekken, maar ook bij privaatrechtelijke onderwerpen ten aanzien waarvan normen of beginselen van internationaal recht bestaan.

Het Nederlandse doorwerkingssysteem is gematigd monistisch ${ }^{39}$ omdat internationaal recht alleen onder de voorwaarden genoemd in de artikelen 93 en 94 Grondwet door de rechter kan worden toegepast:

'Bepalingen van verdragen en van besluiten van volkenrechtelijke organisaties, die naar haar inhoud een ieder kunnen verbinden, hebben verbindende kracht nadat zij zijn bekendgemaakt. ${ }^{40}$

T\&C Grondwet 2015, art. 93 Gw, aant. 6 (Fleuren).

Rb. Rotterdam 25 september 1916, NJ 1917/13.

Handelingen II 1916/17, 346, 2 (ontwerp van wet) en 3 (Memorie van Toelichting).

Kamerstukken II 1916/17, 346, 5, 8.

Bessselink, 'Internationaal recht en nationaal recht' (2007), 64-67.

Art. 93 Grondwet. 
'Binnen het Koninkrijk geldende wettelijke voorschriften vinden geen toepassing, indien deze toepassing niet verenigbaar is met een ieder verbindende bepalingen van verdragen en van besluiten van volkenrechtelijke organisaties. ${ }^{31}$

Deze Grondwetsartikelen vormen een trechter voor de doorwerking van het internationale recht: de Nederlandse rechter mag bepalingen van verdragen en besluiten van internationale organisaties na bekendmaking enkel rechtstreeks toepassen wanneer deze 'een ieder verbindend' (hierna: rechtstreeks werkend) zijn. Hiermee worden bepalingen bedoeld die naar hun inhoud rechtskracht of rechtsgevolg hebben voor particulieren. In principe is het de taak van de wetgever ervoor te zorgen dat een internationale bepaling ook een nationale uitwerking krijgt. De nationale wetgeving kan al in lijn zijn met het internationale recht, maar vaker is het zo dat er nationale wetgeving moet worden aangenomen of gewijzigd om dit met het internationale recht in overeenstemming te brengen. ${ }^{42}$ De rechter heeft vervolgens wel een zelfstandige bevoegdheid: wanneer hij van oordeel is dat een nationaal wettelijk voorschrift niet in overeenstemming is met een rechtstreeks werkende internationale bepaling, dan kan hij in het concrete geval dit nationale recht opzij zetten ten faveure van het internationale recht. ${ }^{43}$ Hij neemt hiermee een actieve rol in ten opzichte van wetgever en uitvoerende macht.

Het is geen standaard praktijk dat de rechter een nationaal wettelijk voorschrift buiten toepassing laat of onverbindend verklaard wegens strijd met een internationale bepaling. Veelal gaat de rechter ervan uit dat de wetgever de internationale verplichting zo goed als mogelijk heeft willen nakomen en probeert hij internationaal en nationaal recht dichter bij elkaar te brengen in plaats van een van beide niet toe te passen. Het voorkomen van een botsing tussen beide rechtsordes is ook in overeenstemming met het pacta sunt servanda uit artikel 26 WVV, het uitgangspunt dat de staat aan zijn internationaalrechtelijke verplichtingen zal willen voldoen. ${ }^{44}$

Wanneer de rechter wél oordeelt dat het nationale recht buiten toepassing gelaten moet worden, ontstaat er veelal een lacune in de nationale wetgeving die moet worden ingevuld. In het ideale geval past de internationale bepaling naadloos in het nationale stelsel en leidt de toepassing tot een bevredigend resultaat. Vaker echter voldoet dit niet en heeft de rechter de keuze uit drie mogelijke oplossingen: het nationale recht volkenrechtsconform uitleggen, zelfstandig rechtsvormend optreden of de rechtsvorming overlaten aan de

41 Art. 94 Grondwet.

42 Kamerstukken II 1979/80, 15049 (R 1100), 10, 10.

43 Besselink \& Wessel, De invloed van ontwikkelingen in de internationale rechtsorde op de doorwerking naar Nederlands constitutioneel recht. Een 'neo-monistische' benadering (Deventer: Kluwer 2009), 50 .

44 Zie bijvoorbeeld Rb. Den Haag 24 juni 2015, ECLI:NL:RBDH:2015:7145, r.o. 4.43 (Urgenda). 
wetgever. ${ }^{45}$ In het Arbeidskostenforfaitarrest overweegt de Hoge Raad hieromtrent als volgt:

'Dat doet de vraag rijzen of de rechter de effectieve rechtsbescherming kan bieden door op andere wijze in het door de regeling veroorzaakte rechtstekort te voorzien dan wel of hij zulks vooralsnog aan de wetgever dient over te laten. In zodanige situaties dienen, met inachtneming van de aard van het rechtsgebied waar de vraag rijst, twee belangen tegen elkaar afgewogen te worden. Voor het zelf in het rechtstekort voorzien pleit dat de rechter daardoor aan de belanghebbende direct een effectieve bescherming kan bieden, maar ertegen pleit dat in de gegeven staatsrechtelijke verhoudingen de rechter bij zulk ingrijpen in een wettelijke regeling een terughoudende opstelling past. ${ }^{46}$

Volgens vaste jurisprudentie van de Hoge Raad wordt het in beginsel aan de wetgever overgelaten om in gevallen waar het internationale recht niet overeenstemt met het nationale recht de rechtspolitieke keuze te maken, zeker wanneer de rechter de gevolgen van deze keuze moeilijk kan overzien. ${ }^{47}$ Anderzijds voorziet artikel 94 Grondwet blijkbaar niet alleen in de bevoegdheid van de rechter tot het buiten toepassing laten van met internationale bepalingen strijdige nationale wetgeving, maar is het bieden van een effectieve rechtsbescherming aan de belanghebbende door de rechter ook van belang. Deze bescherming moet worden afgewogen tegen de gegeven staatsrechtelijke verhoudingen, alhoewel:

'[n]iet uitgesloten is echter dat de afweging anders moet uitvallen ingeval de wetgever ermee bekend is dat een bepaalde wettelijke regeling tot een ongerechtvaardigde ongelijke behandeling in de zin van voormelde verdragsbepalingen leidt, maar nalaat zelf een regeling te treffen die de discriminatie opheft. ${ }^{48}$

Het nalaten van de wetgever om maatregelen te treffen die in de bescherming voorzien, kan voor de rechter dan ook reden zijn om een verdragsbepaling niet rechtstreeks werkt, toch toe te passen. ${ }^{49}$

Uit de artikelen 93 en 94 Grondwet vloeit de bevoegdheid van de rechter voort om het internationale recht rechtsreeks te kunnen toepassen. Dit blijkt ook uit de afweging om een effectieve rechtsbescherming te bieden aan de belanghebbende wanneer de wetgever in deze plicht verzaakt. De staat heeft er immers in alle nationale rechtspraak, een rechtsvergelijkend onderzoek (WODC, 2013), 36.

HR 12 mei 1999, ECLI:NL:HR:1999:AA2756, NJ 2000/170, r.o. 3.15 (Arbeidskostenforfait). HR 10 oktober 2004, ECLI:NL:HR:2012:2928, NJ 2015/12, m.n. E.A. Alkema (Rookverbod). Zie ook: HR 27 september 2019, ECLI:NL:HR:2019:1449, r.o. 3.1.4 (Rookverbod II). 
vrijheid voor gekozen zich te binden aan deze internationale verplichtingen, welke ook hun uitwerking dienen te krijgen in het nationale recht. Hoe de rechter deze rol in de praktijk invult, komt in de volgende paragraaf aan de orde.

\subsection{Mantel of schild: rechtstreekse werking in de praktijk}

De artikelen 93 en 94 Grondwet geven de rechter de bevoegdheid vast te stellen of internationale bepalingen rechtstreeks werken, als gevolg waarvan particulieren een rechtstreeks beroep kunnen doen op de in deze bepalingen neergelegde rechten en plichten. Daarnaast mag de rechter de verenigbaarheid van het nationale recht toetsen aan deze rechtstreeks werkende internationale bepalingen en voorrang geven aan het internationale recht. De praktijk blijkt echter weerbarstiger: de Grondwet geeft geen criteria aan de hand waarvan kan worden vastgesteld wanneer sprake is van een dergelijke rechtstreeks werkende bepaling. 50

Deze criteria zijn door de Hoge Raad geïntroduceerd in het Spoorwegstakingsarrest uit 1986 en bestaan uit verschillende stappen. Allereerst is er de vraag of de verdragsluitende partijen zijn overeengekomen dat aan de bepalingen van een verdrag géén rechtstreekse werking toekomt. Hierover worden vrijwel nooit afspraken gemaakt, dus de rechter zal deze vraag meestal ontkennend beantwoorden. ${ }^{51}$ De vervolgstap bestond uit een keuze voor de rechter: deze internationale bepalingen bevatten óf een verplichting voor de Staat om nationale wetgeving aan te nemen óf ze bevatten rechten welke rechtstreeks kunnen worden toegepast. Daarbij moet de bepaling in abstracto worden beoordeeld - los van de toepassing in het concrete geval. Uitgangspunt hierbij is dat een verplichting voor de staat om wetgeving aan te nemen niet samen kan gaan met de rechtstreekse werking van die internationaalrechtelijke bepaling. Oftewel: wanneer de wetgever in actie moet komen, doet de rechter een stap terug.

Dit arrest en deze criteria zijn in de Nederlandse rechtspraak jarenlang de standaard geweest wanneer het ging om het vaststellen van de rechtstreekse werking van een verdragsbepaling. De rechter gaf hiermee een passieve invulling aan de handhavende rol: ${ }^{52}$ hij kwam in veruit de meeste gevallen tot de conclusie dat de bepaling een verplichting bevatte voor de staat, waardoor zijn eigen inbreng veelal beperkt bleef tot het aansporen van de Staat om wetgeving aan te

50 Wel is er een beperking genoemd in art. 120 Grondwet: de rechter toetst verdragen niet aan de Grondwet.

51 Fleuren, Een ieder verbindende bepalingen van verdragen (2004), 259.

52 Sporadisch paste de rechter wél (normen uit) internationale rechtsbronnen toe, vaak via de reflexwerking of via de handhaving van een minimumstandaard. De reflexwerking houdt in dat internationale rechtsnormen die vanwege bovenstaande stappen níet rechtstreeks kunnen worden toegepast, worden gebruikt om invulling te geven aan (inter)nationale rechtsnormen die door de rechter wél rechtstreeks kunnen worden toegepast. De handhaving van een minimumstandaard komt aan de orde wanneer internationale verplichtingen zijn uitgewerkt in nationale wetgeving, en deze wetgeving wordt gewijzigd waardoor het bestaande beschermingsniveau wordt verlaagd zonder dat hiervoor een rechtvaardiging bestaat. 
nemen. ${ }^{53}$ Voor de rechter bleef weinig ruimte over om 'het Nederlandse recht zoveel mogelijk aldus uit te leggen en toe te passen dat de Staat aan zijn verdragsverplichtingen voldoet', ${ }^{54}$ laat staan om het internationale recht verder te ontwikkelen door interpretatie en toepassing ervan.

Met het Rookverbodarrest brengt de Hoge Raad een wezenlijke verandering aan in het keuzemodel van het Spoorwegstakingsarrest tussen of een verplichting voor de Staat om wetgeving aan te nemen óf rechtstreeks werkend en toepasbaar door de rechter. Het Rookverbodarrest draait om artikel 8(2) Kaderverdrag Wereldgezondheidsorganisatie, dat luidt:

'Each Party shall adopt and implement in areas of existing national jurisdiction as determined by national law and actively promote at other jurisdictional levels the adoption and implementation of effective legislative, executive, administrative and / or other measures, providing for protection from exposure to tobacco smoke in indoor workplaces, public transport, indoor public places and, as appropriate, other public places. ${ }^{55}$

Volgens het gerechtshof Den Haag was de inhoud van de bepaling voldoende duidelijk en daarom rechtstreeks werkend. ${ }^{56}$ De in de Nederlandse Tabakswet vastgelegde uitzondering van het rookverbod voor kleine cafés is met deze bepaling in strijd en moet dus buiten werking blijven. In cassatie voert de Nederlandse staat aan dat artikel 8(2) Kaderverdrag onvoldoende duidelijk is en ongeschikt om rechtstreeks door de rechter te worden toegepast. De Hoge Raad loopt de voor rechtstreekse werking geldende criteria nog eens bij langs en overweegt:

'De vraag in hoeverre een verdragsbepaling rechtstreekse werking toekomt in de zin van de art. 93 en $94 \mathrm{Gw}$, dient te worden beantwoord door uitleg daarvan. Die uitleg moet plaatsvinden aan de hand van de maatstaven van de art. 31-33 van het [Weens Verdragenverdrag]. Indien noch uit de tekst, noch uit de totstandkomingsgeschiedenis volgt dat geen rechtstreekse werking van de verdragsbepaling is beoogd, is de inhoud van die bepaling beslissend. Het gaat erom of deze onvoorwaardelijk en voldoende nauwkeurig is om in de nationale rechtsorde zonder meer als objectief recht te worden toegepast.'57

Zoals vanouds baseert de Hoge Raad zich op de artikelen 93 en 94 Grondwet, maar hij leest deze artikelen uitdrukkelijk in de context van het Weens Verdragenverdrag. Daarmee erkent hij de rol van de internationaalrechtelijke interpretatieregels bij de toepassing en interpretatie van verdragen in het nationale recht. Daarnaast is opvallend dat de Hoge Raad aan de hand van een 
soortgelijke formulering als in het Spoorwegstakingsarrest tot de conclusie komt dat de nationale rechter in het concrete geval een verdragsbepaling rechtstreeks kan toepassen, ook wanneer die bepaling in abstracto een verplichting voor de Nederlandse Staat bevat om wetgeving aan te nemen:

'De enkele omstandigheid dat de wetgever of de overheid keuze- of beleidsvrijheid toekomt wat betreft de te nemen maatregelen ter verwezenlijking van dat resultaat, [belet] niet dat de bepaling rechtstreekse werking heeft. Of van die werking sprake is, hangt af van het antwoord op de vraag of de bepaling in de context waarin zij wordt ingeroepen, als objectief recht kan functioneren. Anders dan de Staat betoogt, betekent het enkele bestaan van keuze- of beleidsvrijheid dus niet dat geen sprake kan zijn van rechtstreekse werking, ${ }^{58}$

De keuze die volgde uit het Spoorwegstakingsarrest - een verdrag bevat óf een verplichting voor de staat om wetgeving aan te nemen, óf kan rechtstreeks door de rechter worden toegepast - wordt met het Rookverbodarrest vervangen door een route waarbij de rechter de rechtstreekse toepassing in het concrete geval beoordeelt, terwijl het verdrag ook de verplichting van de wetgever kan bevatten om nationale wetgeving aan te nemen. Blijkbaar staat de rechtstreekse toepassing van een verdragsbepaling door de rechter in het concrete geval niet in de weg aan de beleidsvrijheid van de wetgever om aan dit verdrag uitwerking te geven in het nationale recht.

Deze doorlopende route betekent een actievere rol voor de rechter: internationale bepalingen waaraan de staat zich heeft gebonden, kunnen in het concrete geval getoetst worden aan de vraag of deze als objectief recht kunnen functioneren. Dit is niet alleen van belang voor de ontwikkeling van het internationale recht, maar ook voor het systeem van de scheiding der machten. Immers:

'[r]echtsstaat en scheiding der machten komen niet in gevaar doordat en wanneer de rechter de staat aan regels en beginselen houdt, maar veeleer wanneer de wetgever allerlei regels maakt maar daarmee kennelijk geen zelfbinding of naleving of consequenties beoogt.'59

De Nederlandse staat is in beginsel vrij zich te binden aan regels van internationaal recht en te bepalen op welke wijze dit recht doorwerkt in de nationale rechtsorde. Tegelijkertijd wordt de staat geacht zich niet in strijd met de door hem aangegane internationale verplichtingen te gedragen. Al het internationale recht dat de staat bindt - zoals verdragen waarbij de staat partij is en gewoonterecht dat voor elke staat geldt - is van toepassing en bindend in de nationale rechtsorde. Internationale afspraken waaraan de Nederlandse staat zich

58 HR 10 oktober 2004, ECLI:NL:HR:2012:2928, r.o. 3.5.3 (Rookverbod).

59 A.W. Heringa, 'Rechter en politiek: verzaakt de politiek/wetgever of dient de rechter juist het belang van de wetgever?', M en R 34 (2016). 
bindt, kunnen ook rechten en plichten bevatten voor particulieren. De rechter heeft de bevoegdheid om deze rechten en plichten rechtstreeks toe te passen.

De verhouding tussen de bevoegdheden van de rechter en de beleidsvrijheid van de wetgever gebaseerd op de internationale verplichting die de staat is aangegaan, sluit aan bij route uit het Rookverbodarrest. Hiermee wordt ook voorzien in het bieden van effectieve rechtsbescherming aan belanghebbenden door de inachtneming van normen uit internationale bepalingen. Zo vervult de rechter wanneer hij het internationale recht interpreteert en toepast naast de legitimerende rol dus ook een actieve handhavende rol met betrekking tot de verplichtingen die de staat is aangegaan. Met een actieve rol voor de Nederlandse rechter staat de nationale rechtsorde niet langer in de weg aan de doorwerking van het internationale recht.

\section{Uitleiding}

Het internationale recht is voor zijn ontwikkeling mede afhankelijk van de nationale rechtsorde. Daarbij is een actieve rol van de nationale rechter van belang. De rechter is een belangrijke schakel in de legitimatie en vorming van het internationale recht en de handhaving van de internationale verplichtingen van de staat op nationaal niveau. Als er internationale afspraken worden gemaakt door de staat, dan is het aan de rechter om deze te identificeren, te interpreteren en toe te passen. Zonder deze taakverdeling zijn de internationale verplichtingen van de staat een loze belofte. Deze bevoegdheid van de rechter is ook af te leiden uit de artikelen 93 en 94 van de Nederlandse Grondwet, maar werd jarenlang passief ingevuld door voorrang te geven aan de verplichting van de staat om wetgeving aan te nemen.

Met het Rookverbodarrest heeft de Hoge Raad de weg geopend voor de Nederlandse rechter om een meer actieve rol op zich te nemen. De rechter kan de internationale verplichtingen van de staat toepassen, juist ook wanneer de wetgever hierin niet (voldoende) voorziet. Meer dan voorheen treedt de rechter naar voren als een gelijkwaardig lid van de trias, vormer van de rechtsstaat. Deze rol hebben zowel het internationale als het nationale recht nodig om zich verder te ontwikkelen. De nationale discussie over de balans tussen de staatsmachten moet daarom ook de internationale rol van de rechter in acht nemen. 